\title{
Optic nerve edema-splenomegaly syndrome
}

INSERM

\section{Source}

INSERM. (1999). Orphanet: an online rare disease and orphan drug data base. Optic nerve edema-splenomegaly syndrome. ORPHA:313800

Optic nerve edema-splenomegaly syndrome is a rare presumably genetic disorder characterized by idiopathic massive splenomeg aly with pancytopenia and childhoodonset chronic optic nerve edema with slowly progressive vision loss. Additional reported features include anhidrosis, urticaria and headaches. 